\title{
Relation Between Syntax Score and Complexity of Carotid Artery Disease
}

\author{
Karotis Arter Hastalığı Şiddeti ile Syntax Skoru Arasındaki İlişki \\ Mehtap Erdogan', @Ramazan Akdemir2, @Mehmet Bulent Vatan² \\ 'Sakarya University School of Medicine Department of Anatomy, Sakarya, Turkey \\ ${ }^{2}$ Sakarya University School of Medicine Department of Cardiology, Sakarya, Turkey
}

\begin{abstract}
Introduction: Carotid artery disease may cause severe constriction or complete occlusion in carotid arteries, it may not give any symptoms until it appears. In some people, stroke is the first finding of the disease. One of the most important causes of stroke is carotid artery stenosis and atherosclerosis causes a total of one third of the stroke. Atherosclerosis; It is a specific finding of both coronary and carotid artery disease.The relationship between carotid atherosclerotic diasease and coronary artery disease (CAD) have been in previous reports
\end{abstract}

Aim: In this study, we aimed to show the relationship between the severity of the carotid artery stenosis(CAS) determined by angiography and the anatomical complexity of CAD assessed by SYNTAX Score (SS).

Material and Method: Our study was carried out in accordance with the Declaration of Helsinki Principles by obtaining the ethics committee approval dated 09.06.17 and numbered E.8640. A total of 45 patients with simultaneously carotid and coronary angiography performed were included in our study. SS, a marker of CAD complexity, was determined by dedicated computer software. The patients were divided into two groups according to the classification of SS: low SS $(n=33, S S<22)$ and intermediate-high SS $(n=12, S S \geq 22$ ) groups. The severity of CAS was assessed by digital subtraction angiography (DSA) of six distinct segments of the carotid artery included the left and right common, internal, and external carotid arteries. Spearman's correlation coefficients were used to determine the correlations between SS and CAS score.

Results: The CAS severity score was significantly higher in patients with intermediate and high SS group than in the low SS group (3/4/4.75 vs. 1/2/3, $\mathrm{p}=0.001)$. There was also significant correlation between $\mathrm{SS}$ and CAS severity score $(r=0.47, p=0.001)$.

Conclusions: We revealed that there was a proportional increase in the severity of CAS to CAD complexity using SS. It may suggest that complex multivascular atherosclerotic disease is the systemic nature of atherosclerosis.

Keywords: Carotid artery stenosis, coronary artery disease, constriction, stroke, Syntax score

\section{Öz}

Giriş: Karotis arter hastalı̆̆ı, karotis arterlerde şiddetli daralmaya veya tam tıkanmaya neden olabilir, ortaya çıkana kadar herhangi bir belirti vermeyebilir. Bazı kişilerde, hastalığın ilk bulgusu inmedir. İnmelerin en önemli nedenlerinden biri karotis arter stenozudur (KAS) ve toplam inmelerin üçte birine atheroskleroz neden olur. Atheroskleroz; hem koroner ve hem de karotis arter hastalığının spesifik bulgusudur. Aterosklerotik karotis hastalığı ile koroner arter hastalığı (KAH) arasındaki ilişki önceki çalışmalarda gösterilmiştir.

Amaç: Bu çalışmada anjiyografi ile değerlendirilen karotis arter darlığının şiddeti ile SYNTAX Skoru (SS) ile değerlendirilen KAH' nın anatomik kompleksliği arasındaki ilişkiyi göstermeyi amaçladık.

Gereç ve Yöntem: Çalışmamız 09.06.17 tarih ve E.8640 sayılı etik kurul onay alınarak, Helsinki Ilkeler Deklarasyonu'na uygun olarak gerçekleştirilmiştir. Çalışmamıza eş zamanlı olarak karotis ve koroner anjiyografi yapılan toplam 45 hasta dahil edildi. KAH kompleksliliği özel bir bilgisayar yazılımı olan SS ile belirlendi. Hastalar SS sınıflamasına göre iki gruba ayrıldı: düşük SS ( $n=33$, SS $<22)$ ve orta-yüksek SS ( $n=12, S S \geq 22)$ grupları. KAS şiddeti, karotis arterlerin sol ve sağ carotis communis, internal ve external bölümlerini içeren altı farklı segmentinin dijital subtraksiyon anjiyografisi (DSA) ile değerlendirildi. SS ile KAS şiddeti arasındaki korelasyonları tespit etmek için Spearman korelasyon katsayıları kullanıldı.

Bulgular: KAS, orta ve yüksek SS grubunda, düşük SS grubuna göre anlamlı derecede yüksekti (3/4/4.75 vs. 1/2/3, $p=0.001)$. SS ve KAD ciddiyeti arasında anlamlı korelasyon vardı $(r=0.47, p=0.001)$

Sonuç: Çalışmamız ile SS kullanarak KAD ile KAS şiddetinde orantılı bir artış olduğunu gösterildi. Karmaşık multivasküler aterosklerotik hastalığın, aterosklerozun sistemik doğası olduğunu düşündürebilir.

Anahtar Kelimeler: Karotis arter darlığı, koroner arter hastalığı, konstriksiyon, inme, Syntaks skoru 


\section{INTRODUCTION}

Atherosclerosis is a systemic process, involving multible arterial territories. ${ }^{[1]}$ Carotid artery stenosis (CAS), that coexists with coronary artery disease (CAD) may indicate an increased burden of atherosclerosis. ${ }^{[2]}$ The presence of significant CAS is directly related to the extent of $C A D$, though the prevalence of severe carotid stenosis was progressively increased among patients with extensive CAD. ${ }^{[3]}$ The progressive concurrent increase of CAS prevalence with $C A D$, suggesting that occurence of shared disease is likely to influenced by similar risk factors such as hypertension, diabetes mellitus, hyperlipidemia, and older age. CAS is an important prognostic marker and risk-stratification tool in patients with CAD. ${ }^{[4,5]}$ Clinical manifestations of CAS are strongly suggestive of clinical events in coronary artery territority. ${ }^{[6-9]}$

The SS is an angiographic score, which represents coronary lesion complexity, has been shown to be useful for predicting clinical outcomes. ${ }^{[11]}$ Previous studies investigated the relationship between carotid artery ultrasound parameters and SS. ${ }^{[12-15]}$ Most of them demonstrated that carotid intimamedia thickness (IMT) has predictive value for coronary artery complexity. ${ }^{[13-15]}$ However, the precise relationship between the severity of CAS and CAD complexity as assessed by the SS has not been evaluated.

In this study, we aimed to investigate the relationship between severity of CAS determined by an angiography and complexity of CAD assessed with the SS.

\section{MATERIAL AND METHOD}

\section{Study population}

The study was carried out retrospectively at a single center from March 2010 to October 2015. A total 614 patients who underwent carotid angiography were analyzed. Amoung them, 45 patients with clinical suspicion of CAD had also coronary angiography performed were enrolled in this study. Patients with a history of coronary or carotid revascularization were excluded. Written informed consent was obtained from all patients and the local ethical committee approved the protocol. Duplex ultrasound and either computed tomography angiography (CTA) or magnetic resonance angiography (MRA) of the carotid arteries were performed in all patients. Carotid angiography was performed in patients with symptomatic internal carotid artery (ICA) stenosis $\geq 50 \%$ or asymptomatic ICA stenosis $\geq 60 \%$ in CTA /MRA. ${ }^{[16]}$ The indications for coronary angiography were as follows: symptoms to suggest cardiac ischemia, physician recommendation based on the presence of clinical characteristics that suggest high risk for CAD and noninvasive testing indicating a high probability of CAD.

All the angiography procedures were performed by two experienced interventional cardiologists. Selective bilateral conventional and digital subtraction angiography (DSA) of carotid arteries was done using 5 Fr Simmons- 2 catheter. The severity of CAS was evaluated by DSA images of six distinct parts of the carotid artery segments which included the left and right common, internal, and external carotid arteries. Each of six carotid artery segments were scored in one of five categories based on their degree of stenosis. The five stenosis categories were included degree of diameter stenosis: 0-49\%, $50-74 \%, 75-90 \%, 90-99 \%$, and total occlusion. The degree of stenosis was calculated by angiography according to North American Symptomatic Carotid Endarterectomy Trial (NASCET) criteria for the common, internal, and external carotid arteries. [17] Low-grade carotid stenosis of less than $50 \%$ is considered to be hemodynamically insignificant. Each of the categories was given a score ranging from 0 to 4, with 0 indicating 0-49\% and 4 indicating total occlusion.Carotid artery severity was calculated in accordance with the study conducted by Long et al. In 1999. In accordance with this study, the total of segments with stenosis of more than $49 \%$ in six segments of the carotid arteries was calculated for each patient. ${ }^{[18]}$

\section{Coronary Angiography and SS}

Coronary angiography was performed by two experienced cardiologists using standard teqniques. CAD was defined as stenosis with a diameter $\geq 50 \%$. According to the baseline coronary angiogram, each coronary lesion producing stenosis with a diameter $\geq 50 \%$ in vessels $\geq 1.5 \mathrm{~mm}$ diameter was scored separately, and these scores were combined to provide the overall SS, which was calculated using the SS algorithm. ${ }^{[1]}$ available on the SYNTAX website (www.syntaxscore.com). ${ }^{[19]}$ A low SS was defined as $\leq 22$, an intermediate score as 23 to 32 , and a high score as $\geq 33 .{ }^{[20]}$ The patients were divided into two groups according to the SS: Group 1 with low risk score (score $<22$ ), group 2 with moderate and high risk (score $\geq 22$ ). We compared groups by CAS score.

Statistical analysis

Statistical analysis was performed by SPSS 20,0 for Windows program.Categorical variables are shown as counts (n) and percentages (\%) and continuous data were presented as the mean \pm standard deviation. Chi-Square test was used to compare the categorical variables. Kruskal Wallis $\mathrm{H}$ test was used to compare the continuous data among low and moderatehigh score groups according to SS (For pairwise comparisons Bonferroni adjusted Mann-Whitney $U$ test

was used). Spearman's correlation coefficients were used to determine the correlations between SS and CAS score. Twosided $p$ values of $<0.05$ were considered statistically significant.

\section{DISCUSSION}

In this study, we have demonstrated a significant association between carotid artery disease severity and coronary artery disease complexity. We also revealed that CAS score was significantly higher in patients with moderate and high SS as compared to low SS group.

Carotid artery disease is regarded as an established marker of generalized atherosclerosis. ${ }^{[2]}$ The prevalence of concomitant atherosclerotic lesion of the carotid and coronary arteries 
increases progressively and is a known predictor of worse outcome in various clinical settings including patients with ischemic stroke, patients undergoing coronary artery bypass grafting and carotid endarterectomy as well as asymptomatic individuals. ${ }^{[21-23]}$ There has been some convincing evidence suggesting that CAD is the leading cause of death in patients who recovering from stroke and patients with asymptomatic CAS are at higher risk for future myocardial infarction than stroke. ${ }^{[4-9]}$ It has been reported that, the coprevalence of $>50 \%$ CAS in patients with CAD is $14.5 \%$ which is $8.7 \%, 5.0 \%$, and $4.5 \%$ in patients with $>60 \%,>70 \%$, and $>80 \%$ CAS, respectively. ${ }^{[10]}$ Furthermore, the prevalence of asymptomatic CAS was progressively increased in patients with extensive CAD. Kallikazaros et al. ${ }^{[24]}$ showed that the prevalence of significant CAS (lumen diameter stenosis of $\geq 50 \%$ measured by carotid Doppler ultrasonography (US) was $5 \%, 13 \%, 25 \%$, and $40 \%$ in patients with single vessel (1VD), double vessel (2VD), triple vessel (3VD) and left main disease (LMD), respectively. In a study conducted on 632 Japanese patients, an ultrasonographic measurement of CAS $>50 \%$ was found in $14 \%, 21 \%, 36 \%$ of patients with 1VD, 2VD, and $3 \mathrm{VD}$, respectively. ${ }^{[25]}$ These investigations were evaluated the coronary artery severity based on the number of the diseased coronary artery. However, none of these studies used. SS which has been approved as a standard method in quantification of coronary complexity. SS does not only provide objectively quantifying of the severity and extent of $C A D$, but also differs from the other methods by allowing us to assess the coronary lesion complexity. ${ }^{[1]}$ Because of its high accuracy and reproducibility, the SS has emerged as a feasible method in clinical use and is useful for decision-making and predicting prognosis among patients who have undergone coronary revascularization. ${ }^{[20,26]}$ In a few studies, a relationship between the carotid Duplex ultrasound parameters and SS of the coronary arteries has been investigated. ${ }^{[12-15]}$ Ikeda et al. ${ }^{[13]}$ demonstrated a significant correlation between the mean carotid intima-media thickness (IMT) and SS. They showed that patients with mean IMT $\geq 0.9 \mathrm{~mm}$ had significantly higher SSs than patients without thickening $(p<0.0001)$. Korkmaz et al. ${ }^{[15]}$ were also found a significant correlation between carotid IMT and overall SS in patients with stable coronary artery disease $(p<0.001)$. Conversely, a study conducted by Costanzo et al. ${ }^{[12]}$ showed that SS was not correlate with prevalence of significant carotid artery stenosis which was defined as $\geq 50 \%$ diameter stenosis calculated by carotid US.

Our study is quite different from the studies listed above. All these studies reporting coexistence rate of both two diseases were based on carotid duplex ultrasound (US) examination. Indeed, carotid IMT has been reported as a surrogate marker of atherosclerotic burden, ${ }^{[27]}$ it does not provide reliable data regarding the significance of the carotid stenosis. The evidence suggests that the risk of stroke directly increases with the severity of carotid stenosis; the patients with $60-69 \%$ CAS has $11 \%$ risk of stroke within 3 years, compared with $32 \%$ for the patients with $\geq 90 \%$ stenosis. ${ }^{[28-29]}$ The studies mentioned above were used carotid Duplex US to determine the severity of the carotid stenosis. Compared with DSA, the "gold standard" test, carotid duplex ultrasound examination is relatively less accurate in the estimation of $\geq 70 \%$ CAS with the sensitivity varied between $87.5 \%$ and $98.6 \%$, and the specificity varied between $59.2 \%$ and $75.7 \%{ }^{[30]}$ Depending on the technical skills and experience of operator, stenosis of carotid lesions can under- or overestimated by carotid US in patients with calcified or inaccessible lesions, tortuous vessels and severe contralateral carotid stenosis.

In this study, we used an angiographic scoring system, indicating the severity of CAS which was obtained from DSA images of six distinct parts of the carotid artery system. This scoring method was defined based on a study conducted by Long et al. ${ }^{[18]}$ We demonstrated that patients with SS score $\geq 22$ had significantly higher carotid artery severity score. It was suggested that in patients with $\mathrm{SS} \geq 22$, CABG offered a survival advantage over percutaneous coronary intervention. ${ }^{[2]}$ Thus, most of them have treated with CABG. Presence of CAS has been shown to be a significant risk factor for peri-post-operative stroke in patients undergoing $C A B G$, with a prevalence of $3 \%$ in unilateral stenosis, $5 \%$ in bilateral stenosis, and 7\% in total carotid occlusion..$^{[10,31,32]}$ Therefore, screening for CAS before CABG in patients with intermediate and high SS may be reasonable.

In conclusion, we demonstrated that there was a proportional increase in the severity of CAS to CAD complexity using SS. In addition we have shown that patients with $S S \geq 22$ had higher CAS severity score as compared to patients with SS $<22$. Therefore, we suggest screening for CAS in patients with complex CAD assessed by SS.

\section{Limitations}

Some limitations should be noted when interpreting our findings. The main limitation is related to our patient selection. The patients included in this study were selected from a group of consecutive patients who were referred for carotid angiography for suspected carotid artery disease. Thus, this sampling bias means that our results concerning the correlation between SS and the severity of carotid artery disease are relevant only to this specific group and the general population. Small sample size is the other limitation of the study. Further large prospective studies with better adjustment for selection bias are needed to confirm our results.

\section{RESULT}

This study revealed a significant relationship between carotid artery disease severity and coronary artery disease complexity. In addition, patients with moderate to high SS had a significantly higher CAD score compared to the low SSd group. Although there have been many studies between carotid and coronary artery disease, this study first evaluated the anatomical lesion distribution and prevalence between the two regions by using SYNTAX Score and Carotid Score. Old studies in the literature have used Carotid Doppler USG to determine the severity of carotid stenosis 
Compared to the "gold standard" test DSA, the carotid duplex USG examination is relatively less in predicting $70 \%$ CAS, with sensitivity ranging from $87.5 \%$ to $98.6 \%$ and specificity ranging from $59.2 \%$ to $75.7 \%$. It is true.

45 patients with simultaneously carotid and coronary angiography performed were included in our study. The study population included 29 men and 16 women with the mean age of $66.7 \pm 8.9$ years. The patients were divided into two groups according to the classification of SS: group $1(n=33, S S<22)$ and group $2(n=12, S S \geq 22)$. The median SS in group 1 and group 2 were 5 (range $0-20$ ) and 28 (range 22-45), respectively. The baseline clinical characteristics such as age, sex, hypertension, diabetes mellitus, hyperlipidemia, and previous history of stroke were similar in the groups. Demographic and clinical variables of the study population are summarized in Table 1.

The CAS severity score was significantly higher in the intermediate and high SS group than in the low SS group $(3 / 4 / 4.75$ vs. $1 / 2 / 3, p=0.001)$ (Figure 1). Also, there was significant correlation between SS and CAS score $(r=0.47$, $\mathrm{p}=0.001$ ) (Figure 2).

\section{CONCLUSION}

According to the results of our study, we have shown that using SS there is a proportional increase in the severity of CAD's CAD complexity. In addition, we showed that patients with $\mathrm{SS} \geq$ 22 had a higher SAD severity score than patients with SS $<22$. Therefore, we recommend screening for CAD in patients with complex CAD assessed by SS.

\section{ETHICAL DECLARATIONS}

Ethics Committee Approval:The study protocol was approved by the Non-invasive Research Ethics Committee of Sakarya University (Permission granted: 09.06.2017, Decision no:E.8640).

Informed Consent: Because the study was designed retrospectively, no written informed consent form was obtained from patients.

Referee Evaluation Process: Externally peer-reviewed.

Conflict of Interest Statement: The authors have no conflicts of interest to declare.

Financial Disclosure: The authors declared that this study has received no financial support.

Author Contributions: All of the authors declare that they have all participated in the design, execution, and analysis of the paper, and that they have approved the final version.

\section{REFERENCES}

1. Ross R. Atherosclerosis-an inflammatory disease. $N$ Engl J Med 1999;340(2):115-26.

2. Rundek T, Arif H, Boden-Albala B, Elkind MS, Paik MC, Sacco RL. Carotid plaque, a subclinical precursor of vascular events: the Northern Manhattan Study. Neurology 2008;70(14):1200-7.
Table 1. Demographic and clinical characteristics of the study population

Parameter

(Demografic features)

SxScore $<22$ SxScore $\geq 22$

Age (mean, SD)

Sex (female, $n, \%$ )

Hypertension ( $n, \%)$

Diabetes mellitus ( $n, \%)$

Smoking ( $n, \%)$

Total cholesterol, mg/dl

LDL, mg/dl

$\mathrm{HDL}, \mathrm{mg} / \mathrm{dl}$

$n=33$

$\mathbf{n}=\mathbf{2 2}$

p value

CASS (median, IQR,IU/ml)

$66.15 \pm 8.9$

$68.2 \pm 8.8$

NS

$12(36 \%) \quad 4(33 \%)$

$29(88 \%) \quad 10(84 \%)$

$10(30 \%) \quad 6(50 \%)$

$3(25 \%)$

$9(27 \%)$

$191 \pm 39$

$177.6 \pm 46.4$

$125,7 \pm 35$

$115.3 \pm 45.3$

$44.9 \pm 14.8$

$45.2 \pm 8.8$

$1 / 2 / 3$

$3 / 4 / 4.75$ artery severity score Data are means \pm SD for normally distributed variables and median for skewed variables or $\mathrm{n}(\%)$ )

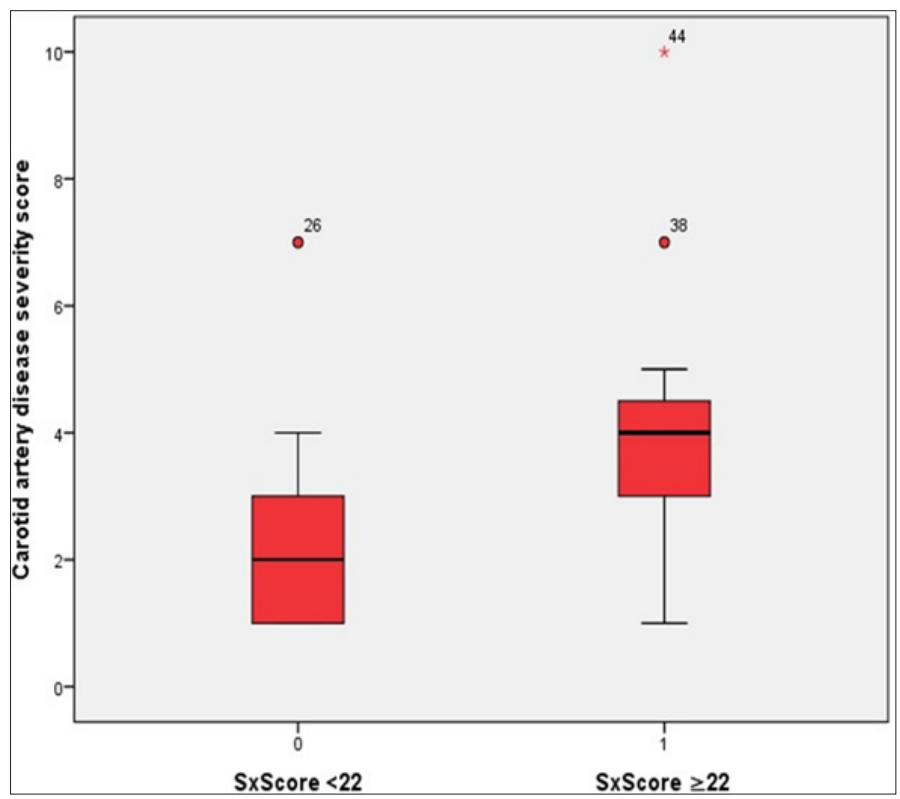

Figure 1. Carotid artery severity score in low and intermediate-high SxScore groups

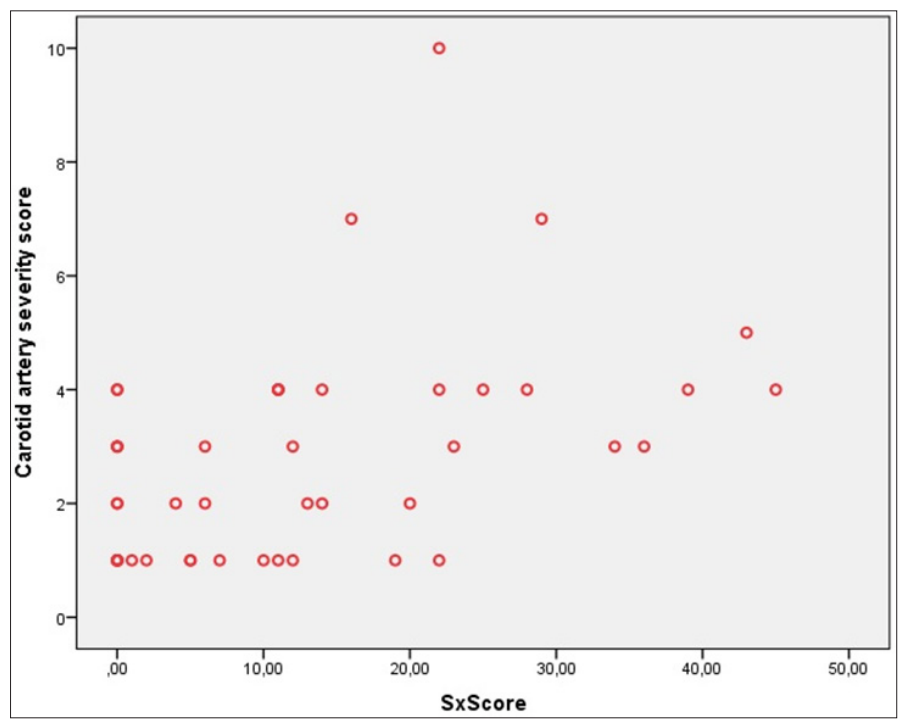

Figure 2. Correlation analysis between carotid artery severity score and SxScore 
3. Steinvil A, Sadeh B, Arbel $Y$ et al. Prevalence and predictors of concomitant carotid and coronary artery atherosclerotic disease. J Am Coll Cardiol 2011;57(7):779-83.

4. Touzé $\mathrm{E}$, Varenne $\mathrm{O}$, Calvet $\mathrm{D}$, Mas JL. Coronary risk stratification in patients with ischemic stroke or transient ischemic stroke attack. Int J Stroke 2007;2(3):177-83.

5. D'Agostino RB, Russell MW, Huse DM, et al. Primary and subsequent coronary risk appraisal: new results from the Framingham study. Am Heart J 2000;139(2Pt1):272-81.

6. Timaran CH, Rosero EB, Smith ST, Valentine RJ, Modrall JG, Clagett GP. Trends and outcomes of concurrent carotid revascularization and coronary bypass. J Vasc Surg 2008;48:355-61.

7. Hankey GJ, Slattery JM, Warlow CP. Transient ischaemic attacks: which patients are at high (and low) risk of serious vascular events? J Neurol Neurosurg Psychiatry 1992;55(8): 640-52.

8. Touzé E, Varenne O, Chatellier G, Peyrard S, Rothwell PM, Mas JL. Risk of myocardial infarction and vascular death after transient ischemic attack and ischemic stroke: a systematic review and meta-analysis. Stroke 2005;36(12):2748-55.

9. Chimowitz MI, Weiss DG, Cohen SL, Starling MR, Hobson 2nd RW. Cardiac prognosis of patients with carotid stenosis and no history of coronary artery disease. Veterans Affairs Cooperative Study Group 167. Stroke 1994;25(4):759-65.

10. Aboyans V, Lacroix P. Indications for carotid screening in patients with coronary artery disease. Presse Med 2009;38(6):977-86.

11. Sianos G, Morel MA, Kappetein AP et al. The SYNTAX Score: an angiographic tool grading the complexity of coronary artery disease. Eurolntervention 2005;1 (2):219-27.

12. Costanzo L, Campisano MB, Capodanno D et al. The SYNTAX score does not predict presence of carotid disease in a multivessel coronary disease population. Catheter Cardiovasc Interv 2014;83(7):1169-75.

13. Ikeda N, Kogame N, lijima R, Nakamura M, Sugi K. Carotid artery intimamedia thickness and plaque score can predict the SYNTAX score. Eur Heart J 2012;33(1):113-9.

14. Ikeda N, Gupta A, Dey N et al. Improved correlation between carotid and coronary atherosclerosis SYNTAX score using automated ultrasound carotid bulb plaque IMT measurement. Ultrasound Med Biol 2015;41(5):1247-62.

15. Korkmaz L, Bektas H, Korkmaz AA et al. Increased carotid intimamedia thickness is associated with higher SYNTAX score. Angiology 2012;63(5):386-9.

16. Tendera M, Aboyans V, Bartelink ML, et al. ESC Guidelines on the diagnosis and treatment of peripheral artery diseases: Document covering atherosclerotic disease of extracranial carotid and vertebral, mesenteric renal, upper and lower extremity arteries: the Task Force on the Diagnosis and Treatment of Peripheral Artery Diseases of the European Society of Cardiology (ESC). Eur Heart J 2011;32(22):2851-906.

17. Ferguson GG, Eliasziw M, Barr HW, et al. The North American Symptomatic Carotid Endarterectomy Trial: surgical results in 1415 patients. Stroke 1999;30(9): 1751-8.

18. Long $\mathrm{TH}$, Criqui $\mathrm{MH}$, Vasilevskis EE, Denenberg JO, Klauber MR, Fronek A. The correlation between the severity of peripheral arterial disease and carotid occlusive disease. Vasc Med 1999;4(3):135-42.

19. SYNTAX score calculator. Available at: http:/www.syntaxscore.com.SYNTAX working-group. Accessed May 2013.

20. Serruys PW, Morice MC, Kappetein AP et al. Percutaneous coronary intervention versus coronary-artery bypass grafting for severe coronary artery disease. N Engl J Med 2009;360(10):961-72.

21. Stamou SC, Hill PC, Dangas G, et al. Stroke after coronary artery bypass: incidence, predictors, and clinical outcome. Stroke 2001;32(7):1508-13.

22. Biller J, Feinberg WM, Castaldo JE et al. Guidelines for carotid endarterectomy: a statement for healthcare professionals from a Special Writing Group of the Stroke Council, American Heart Association. Circulation 1998;97(5):501-9.

23. Aichner FT, Topakian R, Alberts MJ, et al. High cardiovascular event rates in patients with asymptomatic carotid stenosis: the REACH Registry. Eur $J$ Neurol 2009;16(8):902-8.
24. Kallikazaros I, Tsioufis C, Sideris S, Stefanadis C, Toutouzas P. Carotid artery disease as a marker for the presence of severe coronary artery disease in patients evaluated for chest pain. Stroke 1999;30(5):1002-7.

25. Tanimoto S, Ikari Y, Tanabe $\mathrm{K}$ et al. Prevalence of carotid artery stenosis in patients with coronary artery disease in Japanese population. Stroke 2005;36(10):2094-8.

26. Taggart DP. Lessons learned from the SYNTAX trial for multivessel and left main stem coronary artery disease. Curr Opin Cardiol 2011;26(6): 502-7.

27. Sibal L, Agarwal SC, Home PD. Carotid intima-media thickness as a surrogate marker of cardiovascular disease in diabetes. Diabetes Metab Syndr Obes 2011;4:23-34.

28. Walker MD, Marler JR, Goldstein M. Executive Committee for the Asymptomatic Carotid Atherosclerosis Study. Endarterectomy for asymptomatic carotid artery stenosis. JAMA 1995;273(18):1421-8.

29. The European Carotid Surgery Trialists Collaborative Group. Risk of stroke in the distribution of an asymptomatic carotid artery. Lancet 1995;345(8944):209-12.

30. Filis KA, Arko FR, Johnson BL, et al. Duplex ultra- sound criteria for defining the severity of carotid stenosis. Ann Vasc Surg 2002;16(4):413-21.

31. Papadopoulos K, Lekakis I, Nicolaides E. The Predictive Value of the Syntax Score in Patients With Chronic Coronary Artery Disease Undergoing Percutaneous Coronary Intervention or Coronary Artery Bypass Grafting: A Pilot Study. Open Cardiovasc Med J 2017;11:28-32.

32. Ozturk S, Sahin M. Syntax Score I and II for Predicting Carotid Artery Stenosis in Patients with Multivessel Coronary Artery Disease: A Propensity Score Matching Analysis. Braz J Cardiovasc Surg 2019;34(6): 653-8. 